\title{
A simple and low cost injection technique to protect efficiently ornamental Phoenix against the red palm weevil during one year
}

\author{
Susi Gomez and Michel Ferry \\ Phoenix Research Station, Spain, email: sgomezvives@gmail.com; ferry.palm@gmail.com
}

\begin{abstract}
Gomez, S. and M. Ferry. 2019. A simple and low cost injection technique to protect efficiently ornamental Phoenix against the red palm weevil during one year. Arab Journal of Plant Protection, 37(2): 124-129.

Preventive injection treatments in the framework of IPM programs to control the RPW in ornamental palms can present the great advantage to protect them for a long period, but also to transform them in deadly traps for the new weevil generations, contributing thus greatly to the decline of the RPW population. But for the preventive treatments as well as for the other components of the RPW control programmes, it is now essential, given the widespread and abundance of the pest, to propose simple to apply and low cost but also efficient and safe technologies. In this study, a very simple technique was developed based on an infusion process to inject an emamectin benzoate (EMA) formulation, at 3,5\% concentration. The results showed excellent efficiency under different experimental conditions. For the palms of more than 8 meters height, $100 \%$ of the larvae were killed even 360 days after injection, compared to $11 \%$ in the control treatment.

Keywords: Control, injection, emamectin benzoate, RPW.
\end{abstract}

\section{Introduction}

The red palm weevil (RPW) Rhynchophorus ferrugineus Olivier is a phytophagous insect. Its larvae chew the fiber of the internal tissues of palms organs for sucking its sap and dig galleries that are transformed with time to big holes. Such damages are often accompanied with micro-organisms infections that contribute to the death of the palms.

In an infested palm, all the stages of the RPW can be found. In mature and tall palms, infestation starts generally at the base of the leaves base of the inner and middle crowns. Females slip as low as possible between these leaves and dig a small cavity where they lay their eggs. Contrary to what is mentioned for a long time, previous wounds are not necessary for oviposition (ferry and Gomez, 2015). After hatching, the larvae feed, grow and dig galleries, rarely upwards, inside the leaves. After several moults, they migrate close to the leave surface where they form a cocoon with an opening to the outside to allow the exit of the adult. During the second reproduction cycle, the females will most often use the openings and galleries previously made by the larvae to lay their eggs. During the second and following cycles, larvae tend to colonize the leaves bases of the middle crown rather than the central leaves (Ferry and Gomez, 2008).

For RPW control, preventive treatments are mostly applied by soaking abundantly the bases of the leaves each 3-4 weeks. In France, preventive treatments based only on chemical products (excluding neonicotinoids that are now forbidden since September 2018) or alternating chemical products and nematodes are compulsory on all the palms located in the infested areas (Ministère de l'Agriculture, 2010). The application of these treatments is unsustainable in the medium term for economic reasons but also for the

http://dx.doi.org/10.22268/AJPP-037.2.124129

(C) 2019 Arab Society for Plant Protection الجمعية العربية لوقاية النبات risks such chemical treatments impose on health and environment (Ferry et al., 2018).

The use of injection techniques to apply chemical insecticides against the RPW not only can reduce substantially the pollution caused by the traditional treatments (by avoiding environment dispersal when treating, by confining the insecticide into the palm tissue, by reducing the quantity chemical and the number of applications) but also by being more efficient against the RPW, because especially of its capacity to reach the larvae.

The injection of various substances in trees has been implemented for very long time, at least as far as the Hellenistic period. Its use for plant health purpose goes back essentially to the middle of twentieth century, and an important development in with the spread of systemic insecticides in the 70s. The technique triggered numerous investigations and applications that gave place to an important literature (Ferry and Gomez, 2014).

For more than thirty years, injection treatments were applied with success against different serious pests and diseases in oil palms and coconuts plantations in Asia, Latin America and Africa as well as against the RPW on date palm and coconut plantations (Aldawood et al., 2013; El-Ezaby, 1997; Faleiro, 2006; Wood, 1974; Nadarajan et al., 1981). But they have been mainly used as curative treatments. To control RPW in Phoenix canariensis, this technique is in use for around 15 years in the south of Spain (HernandezMarante et al., 2003). In Florida, injection technique is allowed and used to fight against the Lethal Yellowing and the new LPD disease that affect several palm species (Tomlinson, 1990). The opposition sometimes raised against injection in palms was and is still based on frequent serious mistakes committed regarding palms biology, as well as on insufficient knowledge of the existing literature and practices regarding the use of this technique in the world. This 
technique if well applied is obviously of great interest for palms treatments against various pests and diseases.

Thanks to this numerous interconnections (Tomlinson, 1990), even with a small number of injection points, the dispersal of injected insecticides will be excellent at the top of the palm tree. This dispersal is optimum to control a pest like the RPW whose preferential egg laying sites, for the palms without offshoots, are the spear leaves and the leaves of the inner crown. For palms with offshoots, like date palms, injection must be applied as low as possible to allow the insecticide migration, principally acropetally in the stipe through the xylem sap, and, for some insecticides and in lower quantity basipetally through the phloem sap (Ferry and Gomez, 2014).

The success of integrated eradication programs for RPW implies the engagement of important measures and means. Consequently, the programs must be conceived to reach the objective as quickly as possible. The realization of preventive treatments of all palms of the potentially infested zones (100 to 1000 meters around an infested palm or of a trap that has captured RPW) that constitutes an essential component of an integrated program of eradication requires important efforts regarding organization and means (Paz et $a l ., 2010)$. The use of methods which permit the significative reduction of such effort is indispensable to make such programs acceptable and leads to their successful implementation.

The aim of this research is to identify insecticides with long persistence and injection methods easy and not expensive to apply.

\section{Materials and Methods}

For the assessment of injected insecticide effectiveness and persistence, a bio-essay method (Estevez et al., 2011, Gomez et al., 2011) was elaborated. It presents important advantages compared with usual methods. One of the classical methods is based on comparing the health status between treated and untreated palms; it requires to dispose of a large number of palms in the field for robust statistic. A second method requires to sacrifice palms to evaluate larvae mortality. A third one is based on determining the active insecticide residues content.

The method that we elaborated is based on harvesting, at selected intervals of time, the target organs of the treated palms (leaves of adult palms or offshoots) and to feed the RPW larvae with them by introducing the larvae into the tissues of these target organs. They were then maintained in a chamber with controlled conditions with appropriate humidity for several days. Finally, they were dissected to evaluate with high reliability if the insecticide is present at sufficient concentration to kill the larvae. This method is incomparably easier to use than the two first methods previously quoted. In relation to the third method mentioned above, our method allows avoiding erroneous interpretations that can lead to conclude that an insecticide doesn't move or is no more efficient because the active ingredient residue was not detected or present at a very low level, when in fact it has been metabolized to another form also effective against the pest (Gomez and Ferry, 2015).

\section{The insecticide}

The palms were injected with a solution of emamectin benzoate $3,5 \%$ (EMA).

Emamectin benzoate is an avermectin class insecticide developed for the control of lepidopteron insects. This class of pesticide consists of homologous semi-synthetic macrolides that are derived from the natural fermentation products of Streptomyces bacteria. It kills insects by disrupting neurotransmitters, causing irreversible paralysis. It is more effective when ingested, but it also somewhat effective by contact. Target pests are numerous. For the proposed use in tree injection, the target pests include mature and immature arthropod pests. It is lethal upon ingestion or direct contact.

Anses (2014) considered that the injection of EMA formulation does not present risks or presents acceptable risks on the following issues: for the operator and the consumer when applied on ornamental palms; on environment organisms; of water contamination; on bees when palms are not producing nectar, which is the case of Phoenix canariensis.

\section{The palms}

Two groups of Phoenix canariensis were selected for the trials: (1) 24 palms of 3 meters stipe height situated in a parcel in the countryside of the Elche palm grove, Alicante: $38^{\circ} 13^{\prime} 27^{\prime \prime}$ N, $0^{\circ} 41^{\prime} 43^{\prime \prime}$ 'W, (Figure 1); (2) 8 palms of more than 8 meters stipe height situated in a garden in Aspe, Alicante: $38^{\circ} 20^{\prime} 49.65^{\prime}$ N, 0 $0^{\circ} 40^{\prime} 2.76^{\prime}$ 'W, (Figure 1).

\section{Trials}

Trial 1. Height. One of the counterarguments against the use of injections in palms is that the product will never be able to reach the top of very tall palms when injected at the base of the stipe. We have compared the efficiency and persistency of EMA injected in Palms of more than $8 \mathrm{~m}$ versus palms of $3 \mathrm{~m}$ height.

Replicates: 4 palms of more than $8 \mathrm{~m}$ height in public garden conditions compared with 4 treated palms of $3 \mathrm{~m}$ height. Four non-treated palms constituted the control palms of this trial. Number of evaluations were six: 15, 30, 60, 90, 180 and 360 days after treatment.

Trial 2. Another counterargument is that the injected product only could translocate in the palm when the plant is well irrigated. Accordingly, efficiency and persistency of EMA injected in irrigated versus non-irrigated palms were compared.

Replicates: 4 treated and 4 control palms (non-treated) in irrigated conditions (every month by flood irrigation) versus 4 treated and 4 control palms in non-irrigated conditions and in a location with no water table. Evaluation was made four times, 30, 90, 180, 360 days after treatment.

Trial 3. Dose response: three different doses of EMA $3,5 \%(25 \mathrm{ml}, 50 \mathrm{ml}$ or $100 \mathrm{ml}$ of undiluted product). Replicates: 4 palms for each treatment in irrigated conditions. 4 control palms in irrigated conditions. Evaluation was made four times, 30, 90, 180, 360 days after treatment. 


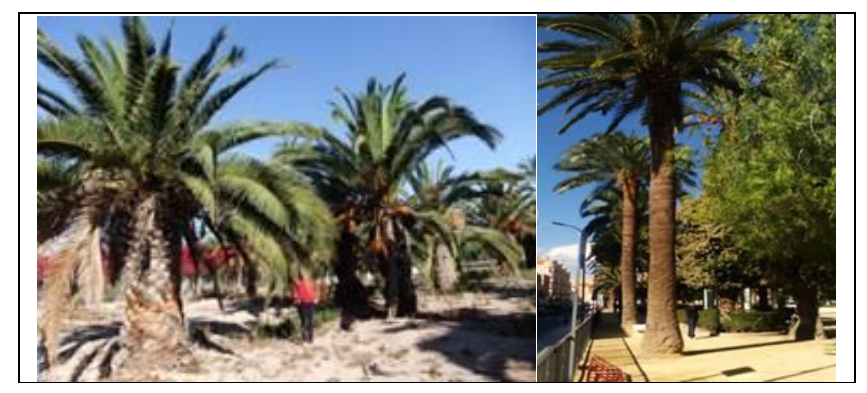

Figure 1. (A) $3 \mathrm{~m}$ canary; (B) More that $8 \mathrm{~m}$ canary palms

\section{Injection method}

For the injection method, we were looking for the simplest, cheapest and safest one. We tested different techniques and we developed a method of injection by infusion that gathered all these qualities. Preliminary trials demonstrated that it was at least as efficient as the other techniques.

The palms were treated once with undiluted product, simply poured in 4 holes drilled at breast heigh in the trunk of each palm, $50 \mathrm{ml}$ of EMA $3.5 \%$ for trials 1 and 2, and the correspondent doses for trial 3 . The size of the holes was proportional to the different doses tested (Figure 2).

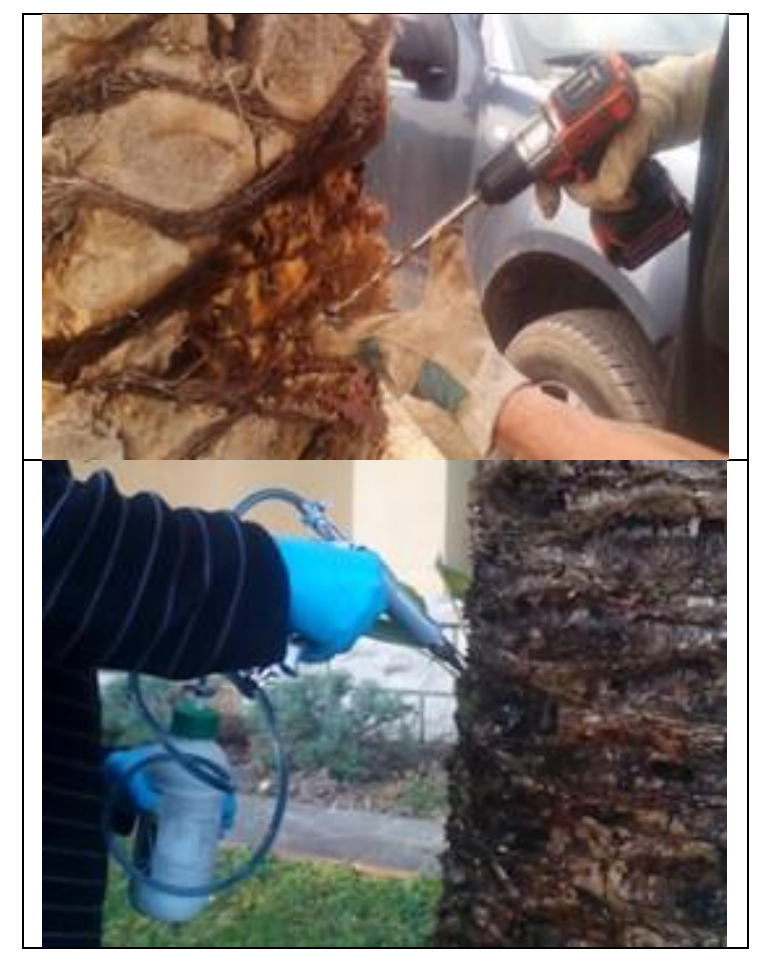

Figure 2. Method of injection

\section{Evaluation}

At different intervals of time, during one year, from each palm, two fronds of the central crown and one spear frond were cut untill their base. Such base constitute for the RPW female the usual target for ovoposition in Phoenix canariensis.

Bioassays were made in the laboratory (Figure 3): at the base of each frond, 3-4 small holes were drilled in which the larvae. One larva of 1 to $2 \mathrm{~g}$ was placed in each hole. 15 days later, the status of the larvae was observed and the still alive larvae were transferred individually to containers containing artificial diet, and frequently observed for 15 days. The same procedure was adopted for the control palms. The larvae were obtained from the rearing unit in our laboratory, using adults captured weekly in the traps placed in an RPW infested area.

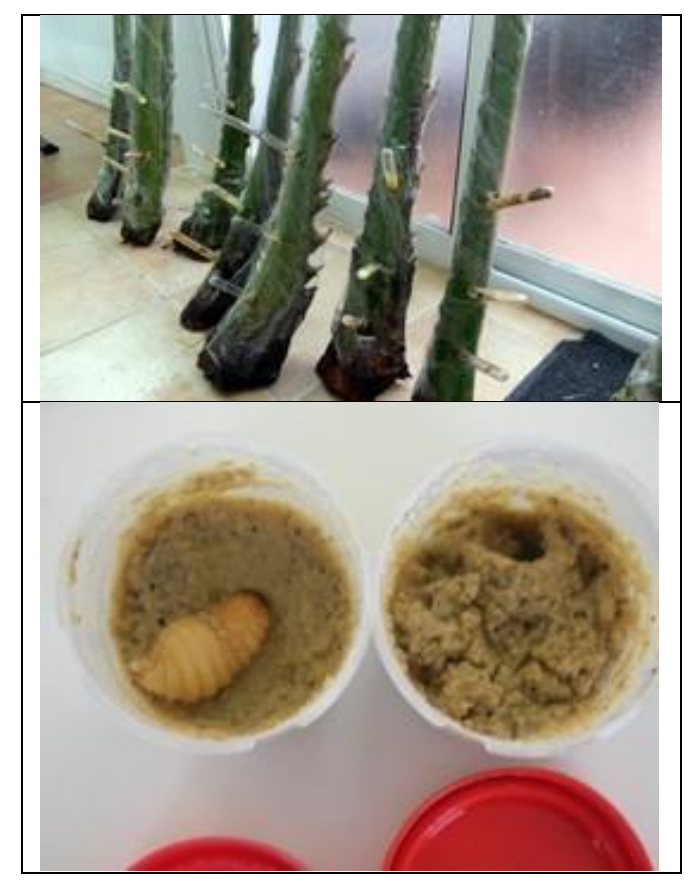

Figure 3. The bioassays

\section{Residue analysis}

A $50 \mathrm{~g}$ sample of each of the leaves bases of trial 3 was taken and sent to the laboratory of the University of Cordoba, Spain, to analyse for the EMA content. Regarding our method concerning residue analysis, Dembilio et al.(2015) argued that our results with this method had to be considered with precaution because the accumulation of active material could also take place in other portions of the leaves and even of the palms. However, what really counted in our research was that the concentration of the active material at the basis of the leaves where the oviposition takes place should be sufficient to kill the larvae and protect the palm.

\section{Phytotoxicity}

The palms treated at the dose of $100 \mathrm{ml}$ were dissected after the last evaluation to control the right compartmentalization of the drilling wounds and an eventual phytotoxicity.

\section{Results and Discussion}

The results showed high efficiency under the different tested conditions. High larvae mortality rate was found (always more than $86 \%$ and $100 \%$ with the tall palms) during a year period in all treated palms. Very few larvae survived after feeding in the leaves of the treated palms. Moreover, the 
majority of these larvae died few days after being fed on artificial diet.

For the palms of more than 8 meters high, $100 \%$ of the larvae were killed even in the leaves harvested 360 days after injection (when the average larval mortality rate of the control was $11 \%$ ). With these tall palms, the results were even better than the best results obtained with the palms of 3 $\mathrm{m}$ height (Figure 4). These results showed that the height of the palms is not a handicap for this technique.

No significant differences were found between larvae mortality rates in trial 2 , when irrigated and non-irrigated palms were compared. Such results suggest that a good level of translocation of the injected chemical occurred even under dry conditions (Figure 5). The same effect was obtained in the trial with different doses, since no significant differences were observed. Only at 360 days, a decrease in all doses was noted (Figure 6).

As for the control (un-treated palms), the mortality of the larvae in the leaves was significantly less (Figure 7) indicating the reliability of the test.

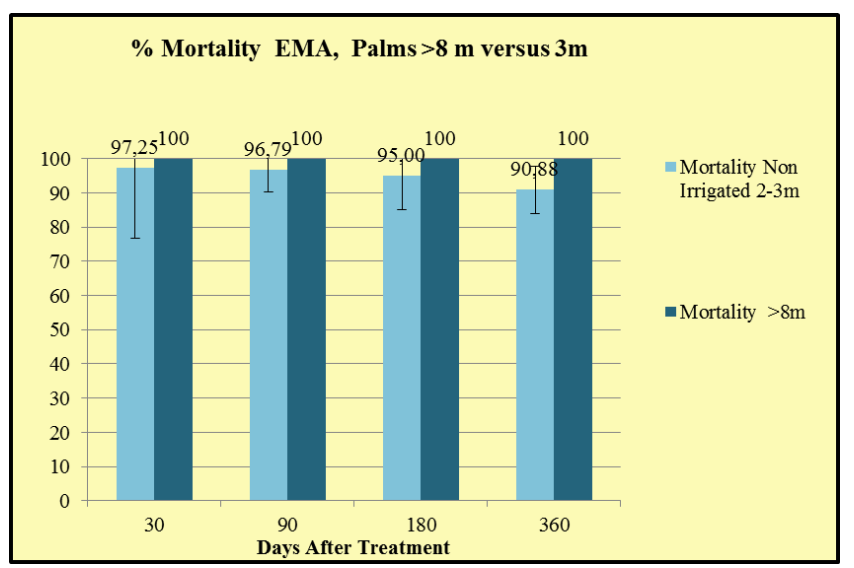

Figure 4. Mortality rate (\%) of larvae feeding in leaves of treated palms ( $8 \mathrm{~m}$ and $3 \mathrm{~m}$ palms).

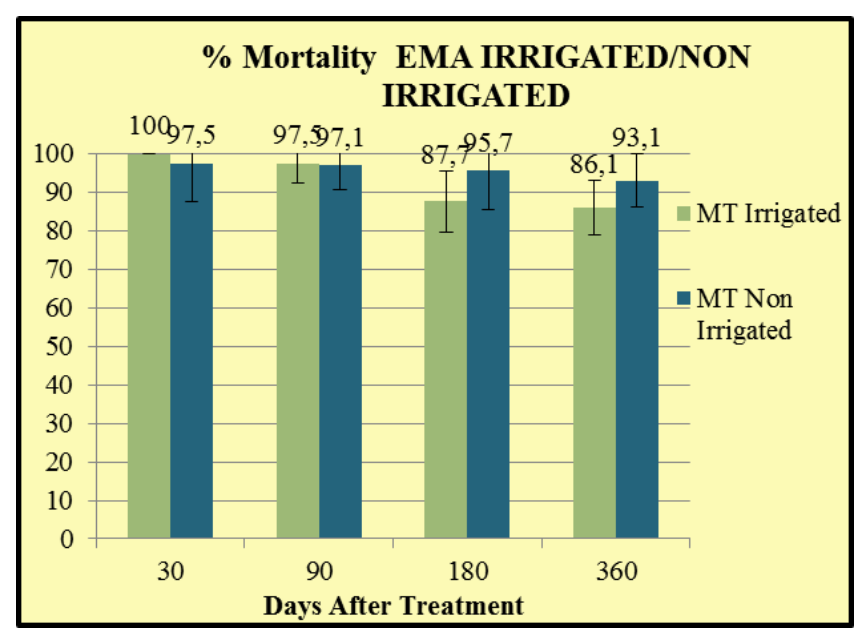

Figure 5. Mortality rate (\%) of larvae in irrigated and nonirrigated palms treated with EMA.

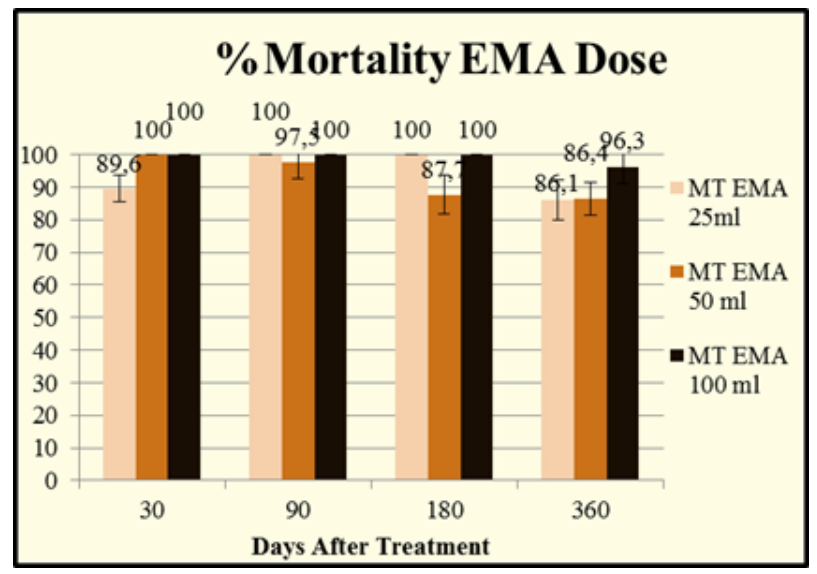

Figure 6. \% mortality in larvae injecting doses of $25 \mathrm{ml}, 50 \mathrm{ml}$ and $100 \mathrm{ml}$

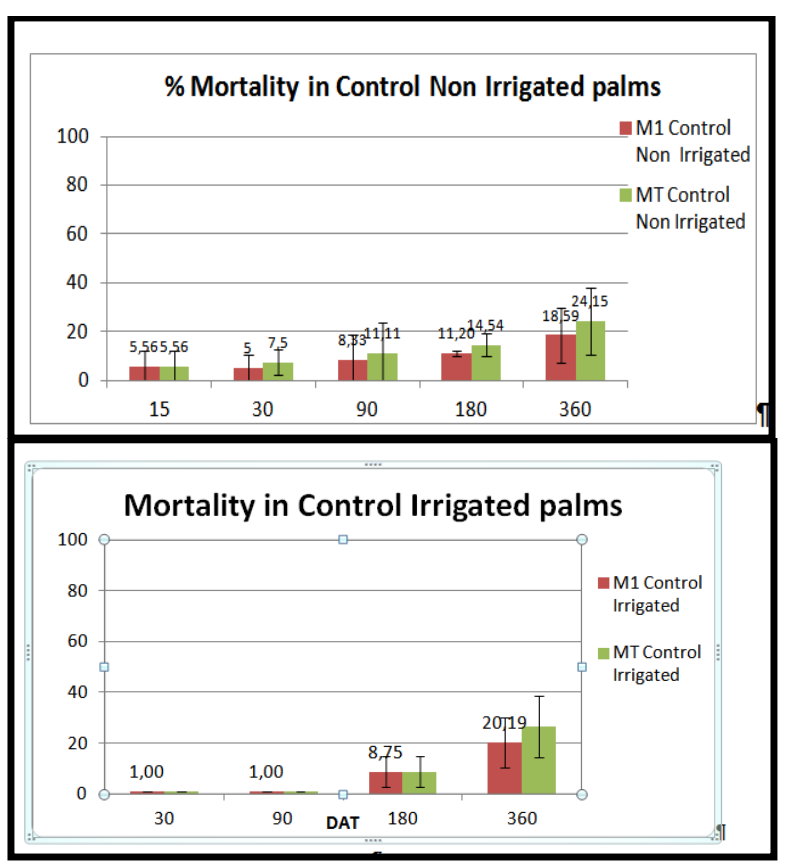

Figure 7. Larvae mortality rate in control palms.

Analysis of EMA residues (ppb) showed a good correlation between doses applied and residues present, with a clear increase of the quantity of active ingredient, untill 90 days after injection. At 180 days after treatment, the variability increased between palms and also between leaves of the same palm. Finally, a strong decline was observed in the EMA residual concentration 360 days after treatment, but this did not prevent a good efficiency against RPW larvae (Figure 8).

Concerning the phytotoxicity study, we dissected completely the four palms treated with $100 \mathrm{ml}$ of EMA looking for signs of phytotoxicity or rot. We found in all the holes a clear phytotoxic effect very localized. In the final end of each hole, the parenchymal tissue and part of the vascular tissue were destroyed forming a necrosis of about $14 \times 4 \mathrm{~cm}$ around the wound, probably caused by the accompanying solvent of the injected solution (Figure 9). We did not 
observe rot or development of fungi, neither leaf phytotoxicity.

It can be concluded from this study that there is high interest in the proposed treatment, especially in urban environment where the palms to protect are generally tall.

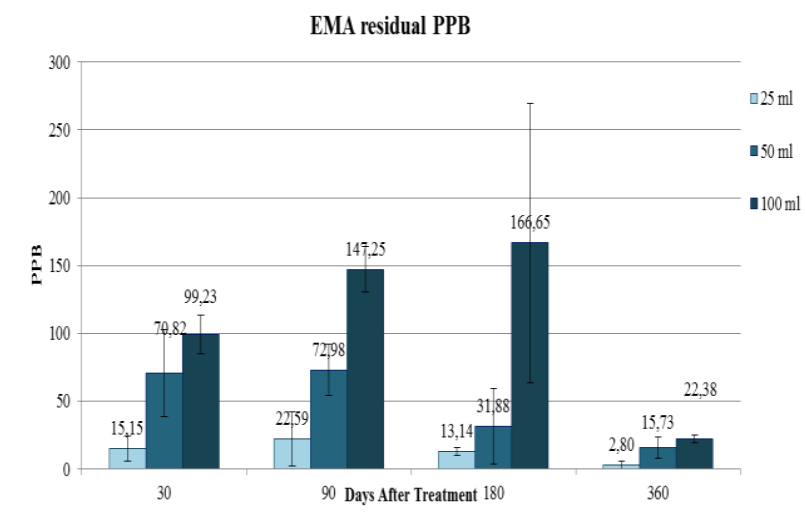

Figure 8. Residual in PPM of EMA in the leaves of the palms injected with $25 \mathrm{ml}, 50 \mathrm{ml}$ and $100 \mathrm{ml}$

One treatment per year, very simple to apply and at a very low cost in the countries where similar EMA formulations are available, constitutes a considerable advantage compared with usual preventive treatments that are delicate and costly to apply in such environment. When this technique was applied on 3000 palms in a heavily infested area in Southern France, less than $1.4 \%$ of the injected palms were infested one year after treatment. (CMSP, 2018).

Nevertheless, damaged tissue because of injection will never be regenerated or recovered contrary to what occurs with trees. Consequently, this technique cannot be used indefinitely; its use should be limited to RPW programmes aimed to reduce quickly the pest population. Its use in plantations for date production must also be excluded because of the long persistence of EMA that generates a risk of chemical residue in the fruits, similar to what has been observed with other injected insecticides

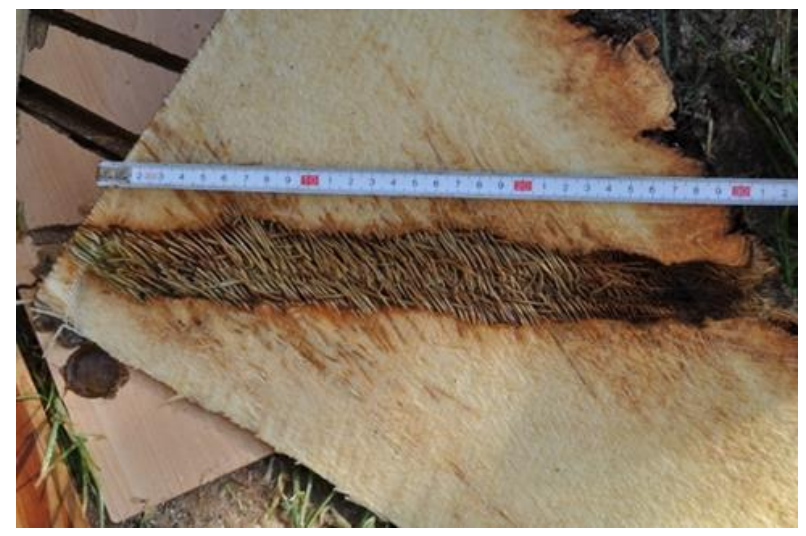

Figure 9. Area of the injection with necrosis at the bottom of the hole

$$
\begin{aligned}
& \text { الملخص } \\
& \text { غومز، سوزي وميشيل فيري. 2019. تقتية حقٍ بسيطة ومنخفضة التكلفة تؤمن حمايةً فعالة لنخيل الزينة إزاء سوسة النخيل الحمراء خلال سنةٍ }
\end{aligned}
$$

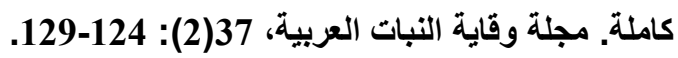

$$
\begin{aligned}
& \text { يمكن أن تتجسّـد الميزة الأهم لمعاملات الحقن الوقائية ضـــن إطـار بر امج المكافحة المتكاملة لسـوسـة النخيل الحمر اء في نخيل الزينة بكونها تؤمّن حمايتها }
\end{aligned}
$$

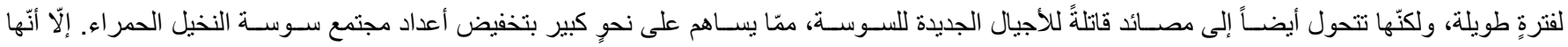

$$
\begin{aligned}
& \text { وكغير ها من عناصر بر امج المكافحة المتكاملة وعلى ضوء الوفرة العددية للآفة وانتشار ها الواسع فقد بات من الضروري بالأسبة للمعاملات الوقائية أن ينمّ اقتراح }
\end{aligned}
$$

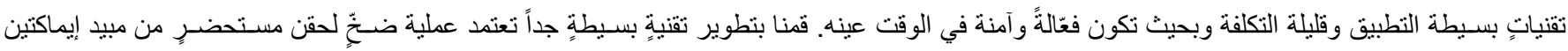

$$
\begin{aligned}
& \text { بنزوات بتركيز 3.5\% . أظهرت النتائج كفاءةً عالية تحت الظروف التجريية المختلفة. وبلغت نسـة قتل اليرقات 100\% في أثـجار النخيل التي يزيد طو لها عن } 8
\end{aligned}
$$

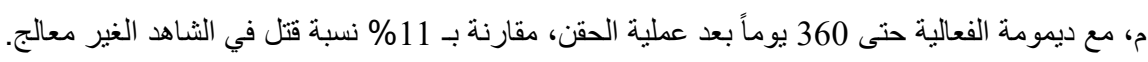

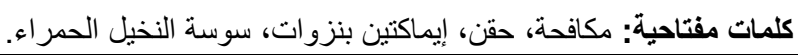

\section{References}

Aldawood, A.S., F. Alsagan, H. Altuwariqi, A. Almuteri and K. G. Rasool. 2013. Red palm weevil chemical treatments on date palms in Saudi Arabia: Results of extensive experimentations. Afpp - Colloque Méditerranéen Sur les Lavageurs des Palmiers- 16, 17 et 18 Janvier 2013, Nice, France. 5 p

Anses. 2014. AVIS de l'Agence nationale de sécurité sanitaire de l'alimentation, de l'environnement et du travail relatif à une demande d'autorisation de mise sur le marché de la préparation REVIVE, à base d'émamectine benzoate de la société SYNGENTA AGRO SAS. 14p.

CMSP. 2018. La lutte collective: seule stratégie pour sauver les palmiers.

Dembilio, O., M. Piquer, M. Barroso, J.M. Riba, M. Gamón and J.A. Jaques. 2015. Movilidad y eficacia del imidacloprid y la abamectina para el control del picudo rojo de las palmeras mediante distintos métodos de aplicación. Agrícola Vergel, Mayo 2015. 170-176 pp. 
El-Ezaby, F.A. 1997. Injection as a method to control the Red Indian date palm weevil Rhynchophorus ferrugineus, Arab Journal of Plant Protection, 15: 3138

Estévez, A., M. Ferry and S. Gómez. 2011. Endotherapy in palms. Study of the efficiency and persistency of thiametoxam in preventive treatments against the red palm weevil. Phytoma, 226: 42-48

Faleiro, J.R. 2006. A review on the issues and management of red palm weevil Rhynchophorus ferrugineus (Coleoptera: Rhynchophoridae) in coconut and date palm during the last one hundred years. International Journal of Tropical Insect Science, 26: 135-154 https://doi.org/10.1079/IJT2006113

Ferry, M. and S. Gómez. 2008. Une nouvelle stratégie contre le charançon rouge des palmiers. Phytoma, 620: 24-28

Ferry, M. and S. Gomez. 2014. Assessment of risks and interest of injection techniques in integrated programs to eradicate the red palm weevil: review and new perspectives. Fruits vol. 69: 143-157 https://doi.org/10.1051/fruits/2014005

Ferry, M. and S. Gómez. 2015. La stratégie de la dernière chance pour sauver les palmiers. Princeps, 1: 125-134

Ferry, M., S. Aldobai and H. Elkakhy. 2018. The state of art of the control of the red palm weevil Presented at the Sixth International Date Palm Conference, 19-21 March, organized by Khalifa International Award for Date Palm and Agricultural Innovation.

Gómez, S., A. Estévez, M. Olmos and M. Ferry. 2011. Development of a new method to evaluate efficiency and persistency of active substances used by endotherapy in adult palms for the control of
Rhynchophorus ferrugineus Olivier. Presented at the VII National Congress of Applied Entomology. 24-28 October, 2011, Baeza, Spain.

Gómez, S. and M. Ferry. 2015. Evaluación de la eficacia y persistencia de emamectina benzoato 3,5\% ME, aplicado por inyección en palmeras canarias adultas, en condiciones de campo, en tratamientos preventivos contra Rhynchophorus ferrugineus. Presented at the SEEA IX Congreso Nacional de Entomología Aplicada, Valencia, 19-23 de octubre 2015.

Hernandez-Marante, D., F. Folk, A. Sanchez and R. Fernandez-Escobar. 2003. Control del curculiónido ferruginoso de las palmeras (Rhynchophorus ferrugineus Olivier) mediante inyecciones al tronco y pulverización foliar. Boletin de sanidad vegetal. Plagas, 29: 563-574

Ministère de l'Agriculture. 2010. Arrêté du 21 juillet 2010 relatif à la lutte contre Rhynchophorus ferrugineus. Modifié par arrêté du 9 Août 2018. 13 p

Nadarajan, L., and G.P. Channa Basavanna. 1981. Trunk injection of systemic insecticides against the coconut black headed caterpillar Nephantis serinopa Meyrick (Lepidoptera: Cryptophasidae). Oléagineux 36: 239245

Paz, S., J. Vidal, M. Ferry and S. Gómez. 2010. Aplicacion de la estrategia integrada de erradicación del picudo rojo en el ámbito de un municipio. Phytoma, 221: 4954

Tomlinson, P.B. 1990. The structural biology of palms, Clarendon Press, Oxford.

Wood, B.J. 1974. Trunk injection of systemic insecticides against the bagworm, Metisa plana (Lepidoptera: Pyralidae) on oil palm. Oléagineux, 29: 499-505 